\title{
CONTEXTUALISATION OF THE GOSPEL AMONG MUSLIMS ${ }^{1}$
}

\author{
M. Coleman ${ }^{2} \&$ P. Verster ${ }^{3}$
}

\begin{abstract}
Contextualisation is considered crucial in relating the gospel to culture. However, when reaching Muslims by means of the Christian gospel it is also important to evaluate the concept of contextualisation, as different approaches enable one to understand the mission to Muslims in different ways. There are still divergent views ranging from total rejection of any aspect of the Muslim culture and beliefs to full acceptance of the Muslim religious culture. Various exponents have attempted in different ways to deal with the issue. Phil Parshall is regarded as a leader in this field. This article suggests a holistic Scriptural view rather than accepting contextualisation as a means to relate the gospel to Muslims. This view is intrinsically bound to Scripture and the acceptance of Scripture as the revelation of God. It is argued that Muslims should be approached with great respect while emphasising the true revelation of God in Christ.
\end{abstract}

\section{INTRODUCTION AND PROBLEM STATEMENT}

Contextualisation of the gospel among Muslims has become a basic and generally accepted principle in modern missions. Yet, it is a challenge to define the meaning, limits, and application of the term "contextualisation", as it relates to missions to the Muslims. A simple, uniform definition of the concept still eludes Evangelicals, Catholics, Baptists, Methodists, Seventh-day Adventists and other Christian denominations and groups that evangelise Muslims. While most missions and missionaries seek to apply the contextualisation theory, the term is so amorphous that there is still no single, widely accepted definition thereof

1 This article is based on the M.A. dissertation of M. Coleman, Pastor of the Seventh-day Adventist Church. Although written from an Adventist perspective, the implications of the research are relevant for a much broader public.

2 M. Coleman, Pastor of the Seventh-day Adventist Church, and post-graduate student, Department of Missiology, Faculty of Theology, University of the Free State, Bloemfontein.

3 Prof. P. Verster, Head: Department of Missiology, Faculty of Theology, University of the Free State, Bloemfontein. 
(Kärkkäinen 2000:261-275). One leading missiologist admits that the term is in fact a description of multitudinous approaches: "It is obvious that a wide variety of meanings, methods, and models are attached to the word contextualization" (Hesselgrave 1995a:115-119). He continues:

Still in its infancy, that word [contextualization] has already been defined and redefined, used and abused, amplified and vilified, coronated and crucified (Hesselgrave 1984:693).

The concept "contextualisation" is an important aspect in mission to and evangelisation of Muslims, as it is based on presuppositions as to how people should be reached by means of the gospel and how their experience should be related to faith in Christ.

What are the views on contextualisation and what are the implications of the various views of Muslim evangelism? Are there acceptable ways of contextualising the gospel in reaching Muslims? This article endeavours to address these questions from a biblical point of view in several steps. Such a response will avoid the extremes of cultural prejudice, on the one hand, and syncretism, on the other. This process includes scrutinising general Christian and Evangelical approaches to Muslim evangelism, investigating the anthropological sources of most theories of contextualisation, conducting a well-balanced and hermeneutically sound study of the Word of God, engaging in responsible theological dialogue with the proponents of various methodologies, and establishing some fundamental biblical principles for the contextualisation of the gospel among Muslims.

\section{CLASSIFICATIONS OF CONTEXTUALISATION}

Various attempts have been made to classify the plethora of variables in contextualised hermeneutical paradigms, contextualised missiological models, and contextualised worship forms, and to create a simplified matrix or continuum. While these have been helpful they have done little to reduce the ambiguity of the concept. Professor A. Scott Moreau, chairman of the Department of Anthropology and Intercultural Studies at Wheaton College, attempted to classify various definitions and approaches (Moreau 2004:1-34). His masterful and comprehensive attempt to synthesise, organise and classify the diversity of contextualised definitions, approaches, and angles of contextualised missions have yielded a dozen definitions, half a dozen paradigms, and at least a score of models. 
Despite the admission by some of the discipline's most notable scholars that it is impossible to define contextualisation in simple terms, Moreau's table of definitions helps to give some structure towards an understanding of the most prominent features of this body of mission theory.

- Contextualisation is dynamic and progressive

For its proponents this is a positive aspect, as it reflects the ever-changing world in which we live. For its opponents this dynamic state of affairs is one of its greatest weaknesses, serving as evidence of its inclination towards syncretism.

- Contextualisation relies heavily on cultural anthropology in its interpretation and application of the Bible

It is universally accepted that the theory of contextualisation would not exist were it not for cultural anthropology (Moreau 1995:121-125, Madany 1995).

- Contextualisation tends towards a localisation of theology

With its emphasis on a given cultural setting and the interpretation of Scripture for such a setting, contextualisation engenders various theologies ultimately arbitrated not by the inspired Word itself, but by the culture. In contextualisation one therefore finds an Asian theology, an African theology, a South American theology, a Muslim-contextualised theology, in fact, a theology contextualised for any group of people, tribe, nation, language and religious background. While it is obvious that for many contextualisers this localisation is only in specific cultural, nonbiblical areas, for others localisation implies the development of a distinct cultural theology or ethno-hermeneutic (Whelchel 2000:125-133). An ethno-hermeneutic is a paradigm of scriptural interpretation rooted in a particular cultural setting.

- Contextualisation tends to interpret historical failures in order to win large numbers of Muslims to Christ as the result of the cultural insensitivity of past generations of missionaries

There are several presuppositions inherent in this line of reasoning (Madany 1995:1-8):

- Large numbers of Muslims not converting to Christianity is interpreted as failure. This article will weigh this assumption on account 
of Scriptural and historical evidence of what constitutes success in missions.

- This "failure" appears to be the result of cultural insensitivity on the part of missionaries - often to the exclusion of other factors among which cultural prejudice on the part of Muslims, the resources and emphasis invested in Muslim missions.

- According to contextualisers, the "failure" of the church to win many converts is considered less of a spiritual problem of the church than an anthropological problem.

These characteristics developed as a manifestation of the theological discussions and questioning that were besetting the Christian church in the 1970s, a decade of great change in the world of Christian mission. In fact, this decade would prove to be a turning point in officially inaugurating the concepts of contextualisation. There were several, somewhat independent, currents in this regard that were to form the framework. Yet, prior to the 1970s, practices and philosophies, some biblical and others not, were afoot that would greatly influence and shape the discussions and decisions of the 1970s.

\section{THE FOUNDATIONS OF CONTEXTUALISA- TION PLACED IN CONTEXT (THE 1970S)}

In a report in 1972, Shoki Coe of the Theological Educational Fund (TEF), a division of the World Council of Churches (WCC), created the term "contextualisation" (Hesselgrave 1995b:139-145). This term was an expansion of the concepts "accommodation", "indigenisation" and "enculturation" which were in use in missiological circles. Coe made it clear that contextualisation was intended to be a new way of theologising.

The theory of contextualisation did not develop in a vacuum. If one were to be true to the principles of the theory, one should admit that contextualisation was a product of its times. It was indeed a culturally conditioned notion that found its impetus in dissatisfaction with the status quo of theological education. Coe implies that the Christian churches in Europe and North America, in the estimation of many, were not theologically prepared for the turbulent 1960s and 1970s. The early seventies were still pitched with the fervour of the vast social and 
political changes taking place in both the developed and third worlds, and at least a few saw the Christian church's interaction with the world as irrelevant to the actual context. Some of the most influential voices of the late 1960s had relegated the Christian churches in general to irrelevant guardians of the status quo whose theology was based on false concepts of colonialism and domination (King 1986:497-504). The church's record throughout World War II in Europe, the colonial era in Africa and Asia, and the American civil rights movement would appear to give historical validity to this appraisal.

In his Third Mandate Programme of the Theological Education Fund (1970-77) Coe underlined a growing realisation and dissatisfaction with theological education. He identified a widespread crisis of faith in the face of the social justice and human development emergency of the times. The WCC sought to address this dichotomy that attested to the church's perceived irrelevance. As Hesselgrave \& Rommen point out, the Council, and Coe in particular, were dealing specifically with social injustice and crisis of faith (Hesselgrave \& Rommen 1989:28) in forming the new concept (Smith 2004:1-10).

Churches which did not form part of the council initially rejected this theory when it was first articulated in 1972. Dr. Charles Kraft (2004) describes the reactions of Christendom:

Though its World Council origins led many evangelicals to at first reject the term, during the mid 1970's, we began to take seriously the broadening of the concept and to find both the term and the discussion useful and instructive (Kraft 2004:1-2).

\section{DIMENSIONS OF CONTEXTUALISATION}

The 1980s saw two significant developments in the theory of contextualisation, namely an acceptance and development of contextualisation in the Christian community at large as well as the development of Muslim contextualised approaches. The aim during this decade was to identify dimensions and ramifications of contextualisation which had not been finally defined. For some, contextualisation primarily involves biblical interpretation (Hesselgrave 1995a:115-119). For others, it is multidisciplinary and involves the application of principles gleaned from the social sciences. Smith simplified the various dimensions of contextualisation into three groups: linguistic contextualisation, involving language forms 
and translation; liberal or syncretistic contextualisation which makes anthropology normative, and modified, moderate contextualisation in which the missionary examines his own preconceived ideas prior to rendering the biblical message as free of cultural baggage as possible (Smith 2004:1-10). While Smith admittedly refers to his classification as basic, efforts at contextualisation do fall into the classifications he suggested. Smith's classification will be used for the purposes of this article.

\subsection{The theme of cultural relevance}

Charles Kraft influenced both the contextualisation theory and Muslim missions in the 1980s. From his position at Fuller Seminary, he worked to expand the theories in the field of cultural relevance and crosscultural gospel communication in his seminal work, Christianity in culture (1979). He argued for the principle of "dynamic equivalence churches" based on New Testament models as the appropriate approach to contextualisation. He also expanded this idea to Muslims (Kraft 1980). Kraft worked on what had been a linguistic principle developed and coined in the 1960s by Eugene Nida, a leader and translator of the American Bible Society.

\subsection{Contextualisation and the theory of dynamic equivalence}

Nida developed the theory of "dynamic equivalence" for the translation of the Bible into traditional languages. According to this theory, the translator seeks a "functional equivalent" to the intended meaning of the original author when translating a message into another language. Taking into account the meaning of the author as he understands it, the translator seeks to transfer this meaning into the new language using equivalent thoughts. He uses numerous anthropological and critical principles to determine what the biblical author meant and then sets out to determine how best to repeat these so that the message elicits the desired response on the part of the receptor in the new cultural setting.

There are at least two major variables in the theory of dynamic equivalence: the translator's understanding of the text and the projected (hoped for) response of the translation's receptors. These variables are, in turn, dependent upon many other variables, the chief ones being biblical hermeneutics and the presuppositions used by the translator to arrive at his understanding of the text. For instance, does the trans- 
lator use a historical-critical model or a grammatical-historical one? Does his view of Scripture allow for substantial errors such as an exaggeration or improper recording of facts? Or does his view of Scripture only allow for grammatical errors made by copyists and scribes? The answers to these variables are potentially momentous in determining the outcome in different meanings in the theory of dynamic equivalence.

The product of this process is said to be "dynamic equivalent", a message as relevant to the receiver in his culture as the message was to the author (biblical writer) in his own culture. Although the substance of the message may have changed significantly in the process, those who use this principle argue that ideally it achieves in the hearer the intended response of the author. It is a basic tenet of this theory that the host culture must hear the gospel in representations that are intrinsically understandable to it (Plastow 1999). The principle of "dynamic equivalence" contrasts with the more traditional "word equivalent" translation method that forces the translator to follow the original text as closely as possible. Many are of the opinion that dynamic equivalence makes the cultural context normative.

There are many examples from mission circles which use this principle. In one example, the term "Ox of God" is used instead of the term "Lamb of God" used in the Bible with reference to Jesus. One author points out how closely the ox is linked to East African Dinka culture (Anderson 1980:1-3). There are so many parallels in their culture between the symbolic roles played by oxen that their hymns and other Christian adaptations of the gospel to their culture refer to the "Ox of God" instead of the "Lamb of God".

In his book New paths in Muslim evangelism Parshall (1980) gives an even more provocative and controversial example when he suggests that a dynamic equivalent for baptism, the Christian initiation rite, should be sought for Muslim converts. His reasoning is that, since Muslims are so resistant to conversion, even to the point of violence, it would be better to find a rite of initiation into the church that would be more acceptable to the culture. His suggestion caused such opposition that he was compelled to retract it. 


\subsection{Dynamic equivalence churches}

Drawing upon Nida's theories, Kraft laid a foundation that would prove to be the basis for much of today's contextualisation theory as it applies to Muslims. He was one of the first to call for the formation of "dynamic equivalence churches" in mission efforts. Paul Heibert (1980), an anthropologist who stressed the creation or use of indigenous forms in worship that provided a functional equivalent (dynamic equivalent) to Western Christian forms, agreed with Kraft.

\subsection{The influence of Phil Parshall}

While numerous individuals continued Kraft's work, none was more influential in the field of the specific application of Kraft's principles to Muslim contextualisation and the development of the definition of the term contextualisation as it applies to Muslim evangelism than Phil Parshall. In his own words, he was longing for a new approach to Muslim evangelism when he returned for furlough from working several years as a missionary in Bangladesh (Parshall 2001:1-4). He enrolled for a Masters programme at Trinity Theological Seminary from 1972 to 1973 where the possibility of applying church development principles to Muslim evangelism first occurred to him. Returning to the field with a team of over twenty individuals he experimented with a variety of Islamic forms and practices, with the exception of the Salat, the Muslim ritual prayer, and accepting the prophetic role of Muhammad. In the late 1970s Parshall enrolled for a Doctoral course under the guidance of Kraft at Fuller Seminary. His doctoral dissertation was published as New paths in Muslim evangelism.

It is interesting to note that Parshall himself later strongly criticised the progressive application of the principles he pioneered in certain areas of Muslim doctrine which he believes should not be experimented with. He believes that efforts at contextualisation in these areas would lead only to syncretism (Parshall 1998:404-406, 409-410). Practices such as praying in the Muslim prayer line, attending prayers at the mosques, accepting Mohammed as a true prophet of God, and conversion of missionaries to Islam are accepted missiological "practices" based upon the principles adopted by Parshall, but which he personally opposes as syncretistic (Massey 2000:5-14). 


\section{FORMULATING A PRECISE DEFINITION}

Having reviewed the major trends and the variety of definitions in the formulation of the theory of contextualisation, one can with a greater degree of accuracy adhere to a definition that encompasses the term. For an understanding of these criteria, one must adhere to the definition of the originator of the term. Although many biblical scholars have attempted to limit the amplitude of the definition and to trim away its historical-critical hermeneutic tendencies, Coe's original definition is the most complete. For the purposes of this article, Coe's definition of contextualisation as an expansion of indigenisation referenced to the times and a new way of theologising will be adopted.

\subsection{Approaches to Muslim contextualisation}

A special issue of the International Journal of Frontier Missions (IJFM), dedicated solely to the topic of contextualisation in Muslim missions, confirms the diversity of approaches. The titles of the articles in this issue of IJFM represent only a small sample of the vast differences that exist in these approaches and methods used by missionaries seeking to raise followers of Christ among Muslims: "Muslim contextualization, God's amazing diversity in drawing Muslims to Christ", "Should Muslims become 'Christians'?", "Jesus in Samaria: a paradigm for church planting among Muslims", "First century Jews and twentieth century Muslims", "The 'Son of God" - Understanding the Messianic titles of Jesus", "Messianic Muslim followers of Jesus and the Ishmael promise and contextualization".

Among the more controversial approaches presented by some theologians, practitioners, and scholars as legitimate evangelistic methodologies and grouped under the general heading of contextualisation are those suggesting that Muslim "converts" to Christ should remain in the mosque, continue to practise Islam and accept the prophetic role of Muhammad. More provocative still is the suggestion by others that missionaries pray at the mosque, accept the prophetic office of Muhammad, keep the annual fast of Ramadan, and consider officially converting to Islam.

Some of the more benign and less controversial approaches include conducting Christian worship services with an Islamic cultural flavour and the adoption of Islamic clothes and dietary practices by Christian missionaries to Muslims (Parshall 1998:404-406, 409, 410). 


\subsection{Arriving at a system of classification}

To help classify the numerous approaches of contextualisation efforts among Muslim peoples and their outcomes, John Travis designed a classification system that arranged the approaches along a continuum that progresses through six stages. The number 1 at the low end of the scale is considered to be an extremely low contextualised approach whereas number 6 at the other end of the continuum would represent the highest, most integrated levels of contextualisation (Massey 2000:5-14).

The development of this continuum has proved to be a useful tool in classifying the various approaches and stages along the scale. However, several authors with vast experience in the evangelisation of Muslims have pointed out that while this progression helps in classifying strategies, it has also created some challenges. For example, Parshall indicates that there is such wide divergence in the usage of the various classifications that it is at times difficult to determine the exact place of a specific approach along the continuum (Parshall 1998:404406, 409-410). For instance, a missionary espousing a C5 approach may officially convert to Islam while a colleague also espousing a C5 level of contextualisation may vehemently oppose such a move as anti-C5. The literature indicates that no satisfactory solution has been found to this dilemma, and Parshall has in fact called for open dialogue and study on this issue (ibid.). The challenge is that there is an inherent weakness in seeking to classify a theory that has an exponential number of possibilities.

\subsection{Using the table and further refinements in classification}

Despite this weakness, the progression chart designed by Travis has become the standard for identifying and seeking to classify the level of contextualisation in which a particular mission agency or missionary is engaged. Contextualisation among Muslims is universally referenced according to this continuum.

$\mathrm{C} 1$ and $\mathrm{C} 2$ churches and missionaries are described as being culturally separate from the Islamic milieu in which they are located except that those at the $\mathrm{C} 2$ level use the local language, avoiding Islamic forms. There are a few Muslim Background Believers in these churches but large accessions of Muslims to these churches are considered practically 
Table III C1-C6 Muslim Contextualisation Continuum

(Adapted from the continuum created by John Travis)

\begin{tabular}{|c|c|c|c|c|c|c|}
\hline & $\mathrm{C} 1$ & $\mathrm{C} 2$ & $\mathrm{C} 3$ & $\mathrm{C} 4$ & $\mathrm{C5}$ & C6 \\
\hline $\begin{array}{l}\text { Body of } \\
\text { believers }\end{array}$ & $\begin{array}{l}\text { A church } \\
\text { foreign to } \\
\text { the } \\
\text { Muslim } \\
\text { host cul- } \\
\text { ture both } \\
\text { in cultural } \\
\text { practices } \\
\text { and lan- } \\
\text { guage. }\end{array}$ & $\begin{array}{l}\text { Like C1 } \\
\text { but speak- } \\
\text { ing the } \\
\text { language } \\
\text { used by } \\
\text { Muslims, } \\
\text { though } \\
\text { their reli- } \\
\text { gious ter- } \\
\text { minology } \\
\text { is dis- } \\
\text { tinctly } \\
\text { non- } \\
\text { Muslim. }\end{array}$ & $\begin{array}{l}\text { Like C2, } \\
\text { but using } \\
\text { non- } \\
\text { Islamic } \\
\text { cultural } \\
\text { elements } \\
\text { (e.g., dress, } \\
\text { music, } \\
\text { diet, and } \\
\text { arts). }\end{array}$ & \begin{tabular}{|l} 
Like C3 \\
but with \\
some \\
Biblically \\
acceptable \\
Islamic \\
practices.
\end{tabular} & $\begin{array}{l}\text { Like C4 } \\
\text { but with a } \\
\text { "Muslim } \\
\text { follower } \\
\text { of Jesus" } \\
\text { self iden- } \\
\text { tity. }\end{array}$ & $\begin{array}{l}\text { Secret be- } \\
\text { liever may } \\
\text { or may not } \\
\text { be active } \\
\text { in the reli- } \\
\text { gious life } \\
\text { of the } \\
\text { Muslim } \\
\text { communi- } \\
\text { ty. }\end{array}$ \\
\hline $\begin{array}{l}\text { Generic } \\
\text { term }\end{array}$ & Christian & Christian & Christian & $\begin{array}{l}\text { Follower } \\
\text { of Issa }\end{array}$ & $\begin{array}{l}\text { Muslim } \\
\text { follower } \\
\text { of Issa }\end{array}$ & $\begin{array}{l}\text { Privately } \\
\text { follower } \\
\text { of Issa, or } \\
\text { Muslim } \\
\text { follower } \\
\text { of Issa }\end{array}$ \\
\hline Name & Christian & Christian & Christian & $\begin{array}{l}\text { A type of } \\
\text { Christian }\end{array}$ & $\begin{array}{l}\text { A strange } \\
\text { type of } \\
\text { Muslim }\end{array}$ & Muslim \\
\hline
\end{tabular}

unthinkable due to the cultural gulf separating these churches from the Islamic culture. Contextualists refer to this approach as "traditional" evangelism, and the literature describes such an approach as ineffective and undesirable.

$\mathrm{C} 3$ and $\mathrm{C} 4$ approaches use cultural and Islamic forms in the worship service, with $\mathrm{C} 3$ practitioners still clinging to a "traditional" Christian service. C3 churches use Islamic terms as well as certain cultural elements in their worship of Allah while the liturgy of C4 churches closely reflects a re-interpreted Islamic one. Believers and missionaries are also 
encouraged to adopt Islamic lifestyle elements such as abstaining from pork and alcohol, and Islamic dress.

According to literature, C6 contextualisation is hardly a theory or methodology but rather a survival mechanism for those living in areas where open profession of faith in Christ and conversion to Christianity would mean annihilation. C5 experiences the greatest level of confusion and controversy. Such confusion is mostly related to Christian missionaries' use of Islamic forms as evidenced by Parshall's concerns.

In a further attempt to clarify and organise the various approaches to Muslim ministry and contextualisation, Parshall adds his own insights to the meanings and categories of the C1-C6 spectrum. His insights preserve Travis's explanations except that Parshall expands his description of the C5 level of contextualisation (Parshall 1998:404406, 409-410). He expresses concern for the tendency of C5 contextualisation theorists to slip into what he considers to be syncretism. $\mathrm{He}$ has in fact suggested that anything beyond C4 is syncretism (ibid.)

\subsection{The C4/C5 controversy}

C5 contextualisation (and sometimes C4) is the centre of controversy in most of the literature on contextualisation among Muslims. $\mathrm{C} 4 / \mathrm{C} 5$ is the level at which believers are often encouraged, among other controversial practices, to remain in the mosque and to call themselves Muslims; missionaries are often encouraged to convert to Islam (Douglass 1994:69-73); Mohammed is accepted as a prophet and the Koran is accepted as one of the holy books. C5 proponents suggest two lines of reasoning for their approaches. Many, if not most, Islamic forms are redeemable. This supposition is based on another reasoning, namely that Islam is a religion with essentially similar monotheistic and God-inspired roots as Judaism and Christianity (Eenigenburg 1997:310-315).

\section{REVISITING HERMENEUTICS}

Several autors repeatedly mention the theological inconsistency of $\mathrm{C} 5$ proponents' common use of 1 Corinthians 7:17-24 and similar sections from Scripture as a basic principle for imitating Muslim practice and encouraging continued Islamic involvement and identification of new believers (Leffel 2004:1-14). 
As this review has shown, the link between contextualisation theory and hermeneutic principles is strongly established in the literature. This theme runs as an often overlooked undercurrent to every debate on appropriate contextualisation levels. One example of this underlying hermeneutic tension is the discussion relating to the inclusion of the Koran as a holy book by Christian missionaries.

In the case of $\mathrm{C} 4$ and $\mathrm{C} 5$ contextualisation (those levels that accept the divine inspiration of the Koran), Samuel Schlorff has argued that a vague and ill-defined Biblical hermeneutic is employed in Christian referencing of the Koran as a holy book (Schlorff 1980a:143-151). His rational and cogent argument is that the Christian use of the Koran to support biblical truth can only be successfully accomplished by using a biblical hermeneutical approach to the Muslim holy book. This is no more acceptable to Muslims than the use of a koranic hermeneutical approach to the Bible, a method popularised by famed Muslim apologist Deedat (1983). Schlorff highlights and seeks to address the theological void not filled by popular contextualisation theory. He has called for a new apologetic towards Islam, one that avoids the dogmatic errors of past centuries, is appealing to Islam and is firmly based on biblical truth (Schlorff 1980b:335-366).

\section{THE EVANGELICAL CONTRIBUTION: CONTEXTUALISATION OF THE GOSPEL MESSAGE AMONG MUSLIMS}

Since the birth of modern missions, the most successful missionaries have always practised biblically sound cultural adaptations of lifestyle, language, and expression in seeking to reach the world by means of the gospel. Previous efforts at cross-cultural communication of the gospel in a culturally sensitive way were usually referred to as "indigenisation" or one of several related terms. Another related term was "enculturation" which had a similar connotation as the terms based on the root word "indigenous" (Plastow 2004:1-3). Many of the practices presently understood to be contextualisation, aimed at reducing the foreignness of the missionary and his message to his hearers/receptors, were put into practice long before Coe introduced the concept of contextualisation in 1972 (Kraft 2004:1-2). The biblical mandate for missionaries to seek 
to adapt culturally to their audience is clear. Paul stated "I am made all things to all men that I might by all means save some" (1 Corinthians 9:22). William Carey mastered the Bengali language while learning Sanskrit and Hindi in translating the Bible (Wellman 1997:119-132); Hudson Taylor and associated missionaries adopted local dress and conducted worship in eastern-style buildings. In the 1860s Taylor was committed to using what one author termed "amoral" cultural forms as a "courtesy to the natives" (Christie 1999:132). The Cambridge Seven, seven young men who joined Hudson Taylor in the China Inland Mission, also adopted local dress and learned to speak the local language, using cultural forms wherever it was biblically permissible, to teach the gospel (Pollock 1955). David Livingstone identified so fully with his Makalolo tribesmen that he could trust them as they travelled on foot through dense wilderness and among hostile tribes (Wellman 1995:109-143).

Although these early attempts at adaptation would now neatly fit into the contextualisation continuum, none of these missionaries used a particular term for the process of learning, adaptation, and assimilation required in their work. Each wrestled with his own value systems and surrendered, often painfully, cherished opinions, ways and thought patterns that would hamper effective propagation of the gospel. Certainly the incarnational ministry of Jesus sets the standard for all missionaries to strive to adapt their person, lifestyle and views to those of the people they want to reach with the gospel. Divesting oneself of one's own cultural, prejudicial views and seeking to present the gospel in terms unencumbered by the views, attitudes, and background of the missionary can justifiably be called a biblical mandate (1 Corinthians 9:12-25). This realisation has caused good missionaries to adapt themselves and the words and images they used into terms and images familiar to the hearers, as far as the Bible would permit.

However, when the discussion of contextualisation in Evangelical circles is applied to the Muslim world, the crux of the dissension and discussion among both proponents and antagonists of contextualisation theory does not centre on simple cultural adaptations. The nature of religion and its place in culture, while an issue, is not the focus of the debate. To dress as Muslims, to greet as the locals do, and even to observe some of their dietary rules are considered purely cultural and do not engender the heated debate of other more "highly developed" 
forms of contextualisation (Douglass 1994:69-73). The use of "amoral" cultural forms is not a new ${ }^{4}$ trend. As has been demonstrated, this form of missionary adaptation has occurred since the birth of modern missions.

Contextualisation up to the $\mathrm{C} 3^{5}$ level, the level which seeks to use amoral or "biblically permissible" cultural forms in evangelisation efforts to Muslims, is, with a few exceptions, an extension into Muslim ministry of principles long used by missionaries such as Hudson Taylor among Buddhists and others in the China Inland Mission and by many others in other places. By definition C4 contextualisation is an attempt to use biblically acceptable cultural practices in mission efforts (see Table III). Yet, even among C4 contextualisers the debate as to where contextualisation stops and syncretism begins is far from settled (Parshall 2004:288-293). Missiologists such as Heldenbrand see C4 as moving towards syncretism, because the principles upon which it is based are similar to those for C5 (Williams 2003:75-91).

\subsection{Clearing the confusion related to mandates}

Christians must redefine what contextualisation means for them as a prerequisite for an understanding of Christian ministry among Muslims. As this article has clearly demonstrated, to accept the commonly held evangelical definitions of contextualisation is to become enmeshed in an array of often contradictory and conflicting theological opinions and missionary practices. The better alternative is to adopt a holistic approach of missionary effort. This approach is perfectly placed in context; it satisfies the theological fidelity required by the Bible while being adaptable to meet the people where they are. The essence of this approach is that the Biblical foundation is not debatable.

4 By "new" we mean any concept that arose after contextualisation was fully accepted in Evangelical circles since the early 1980s.

5 The point here is that although the C1-C6 continuum was not in existence before the 1980s, missionaries have always practised common sense adaptations to the local surroundings based on clear and sound Bible principles. This assertion is a rejection of the implication that all cultural sensitivity in cross-cultural gospel communication is contextualisation. 


\subsection{Developing an alternative, holistic apologetic}

A holistic Scriptural approach should be accepted as an appropriate description of the way in which mission to the Muslims should be conducted, as opposed to contextualisation, as it is a concept based on Scripture, adequately expressing all aspects of God's revelation in Scripture relating to mission. The notion of the whole gospel to the whole person is the starting-point. In this regard syncretism should be avoided. This can be effected by emphasising the biblical revelation as essential for the way in which Muslims are approached. This article contends that syncretism can be avoided by emphasising biblical revelation. The Bible is the source that gives guidance on establishing the non-negotionable aspects of the Christian faith.

An holistic approach to Islam should be based on an alternative apologetic. The apologetic currently in vogue in Christian circles involves appeasing Islamic anger and making concessions to certain Islamic misunderstandings of Christian teaching. It is a kind of trade-off. We will accept some of their propositions if they will accept ours. Evangelicals have called for a careful, Scriptural attitude in the face of the prejudices and presuppositions that Islam brings to the Christian-Muslim debate, realising the ineffectiveness of the confrontational apologetic of the past (Schlorff 1980b:335-366). A confrontational approach should be avoided without compromising the gospel.

A consistent apologetic to Islam may include themes such as the judgement, healthy living (including alcohol and tobacco abstinence), modesty and women (an important Islamic theme), an honest biblical appraisal of the errors and sins of Christianity throughout history, the antichrist (a theme discussed in Islamic hadith literature), the last days (a pillar of Islam), the return of Christ (although distorted, this is a koranic theme), and prophecy. Such apologetic must necessarily include the production of materials for the purpose of evangelising Muslims, because as Borge Schantz states:

Much of the Christian literature on Islam deals with Islam as a religion and how to relate and witness to Islamic people. Still more volumes, like this manual are written to teach Christians how to relate and witness to Islamic people. Very few publications are written to explain the Christian faith to Muslims (Schantz 1993:19). 
The holistic approach takes cognisance of the fact that any Christian working for the salvation of Muslims must realise that the Muslim way of thinking and relating to life differs in many ways from his or hers. The Muslim's view of the world and his interaction with it differ from those of the Christian because, despite certain similarities, Islam and Christianity differ in many other respects. The differences are even more pronounced in the case of a missionary from the Western world. Islam carries with it a set of presuppositions, viewpoints and attitudes that are so different from those to which a Christian from a non-Islamic background is accustomed that careful study, observation, and research are required in order to have some notion of Muslim life. Yet what does the missionary gain from his study and research? Does he gain a knowledge which he can reduce into a set of do's and don'ts, a guide to Muslim mission? At the very least he should have an understanding of what Bill Musk calls the "prevailing norms" of Muslim society (Musk 1995:19). Prevailing norms are those ideologies that underpin all Muslim societies in a greatly diversified Muslim world. Musk makes the pertinent point that a Christian wishing to share the good news of the gospel with Muslims should not only have a checklist of guidelines of proper etiquette and cultural cues but also understand the Muslim attitudes to and assumptions concerning reality that lie at the heart of his way of relating to the world.

\subsection{A high view of Scripture}

The tendency to slip into humanistic reasoning which views the Scripture as a book with both inspired and uninspired sections that can be separated by the professed scholar or critic is irrevocably harmful to Muslim evangelism. The Muslim worldview is absolute. Their concept of their divinely inspired book, the Koran, allows for no equivocation in areas of mistakes and historical errors although to the Christian the Koran is riddled with errors. How can a Muslim gain respect for the Bible when its proponents and advocates treat it irreverently and suggest that the God-inspired book is simply a Jewish expression of their concept of God? For Scriptural and socio-cultural reasons a high view of Scripture is ultimately the only consistent approach to Muslims (2 Timothy 3:16). 
Simple and direct materials, in many languages, must be tactfully adapted to the Muslim mindset, and present simple Bible truth. Biblical themes to which Muslims can readily relate such as the judgement, angels and prophets can be presented, not in the highly contextualised fashion of tacit acceptance of Muslim beliefs, but in the spirit of the simple presentation of what the Bible teaches. Many Muslims are surprised to findthat there are Christians with whom they can agree and that the Bible teaches issues they had never thought possible.

The Seventh-day Adventist Church has officially opposed historical critical hermeneutics. This is reflected in their document "Methods of Bible Study", accepted in 1986 in Rio de Janeiro, in which the following principles are set out:

(1) The Bible is the Word of God and is the primary and authoritative means by which He reveals Himself to human beings.

(2) The Holy Spirit inspired the Bible writers with thoughts, ideas, and objective information; in turn, they expressed these in their own words. Therefore the Scripture is an indivisible combination of human and divine elements, neither of which should be emphasised to the neglect of the other.

(3) All Scripture is inspired by God through the work of the Holy Spirit. However, it did not come in a continuous chain of unbroken revelations. As the Holy Spirit communicated truth to the Bible writer, each wrote as he was moved by the Holy Spirit, emphasising the aspect of truth which he was led to stress. For this reason the student of the Bible will gain an understanding of any subject by recognising that the Bible is its own best interpreter and, when studied as a whole, it depicts consistent, harmonious truth.

(4) Although it was given to those who lived in the ancient Near Eastern/ Mediterranean context, the Bible transcends its cultural backgrounds to serve as God's Word for all cultural, relational and situational contexts.

\subsection{The divine-human Christ as the Son of God and Son of man}

This subject remains problematic for contextualisers. Studies have shown that among C5 Muslim converts the understanding of the Trinity and the role of Christ as Son of God are extremely weak areas (Parshall 1998: 
404-406, 409-410). Contextualisers are extremely sensitive when broaching this topic with Muslims. The replacement of the name Isa al Masih in translations for Jesus or Son of God by C4 and C5 contextualisers is more than a mere adaptation of a Muslim word. It effectively alleviates the pressure of having to deal with one of the most controversial Biblical doctrines for Muslims. It is increasingly advocated that Muslims stay Muslims and "accept" Isa al Massih (Travis 2000:53-59). The Koran references to the fact that God has no son are well known. Many have attempted to spiritualise away the term "Son of God" in an attempt to pacify Muslim disdain of this doctrine. The truth of the Trinity should, however, never be compromised.

\subsection{The issue of lifestyle}

The holistic approach demands a lifestyle that is consistent with the Biblical standards of modesty and decorum. Many devout Muslims are horrified at the apparent lack of propriety and reserve displayed in the Christian West. Missionaries to Muslims have the happy privilege of showing that true Christianity does not reflect or imbibe the decadence of Western culture.

\section{A FINAL WORD}

It is doubtful that it is possible to pick and choose from contextualised ideology, use it, and still avoid the underlying principles. Much of contextualisation theory finds its sources in humanist anthropology. If, in our efforts to reach Muslims with the gospel, we accept high-spectrum contextualised efforts such as those outlined in this article we run the risk of creating spiritual and cultural dilemmas which we are unable to solve.

However, rejecting high-spectrum contextualisation is not tantamount to cultural insensitivity and lack of respect or tact. Every consistent approach developed by Christians will be tactful and filled with the love of Christ as it will be based on his Word.

The holistic Scriptural approach is the adoption of a truly biblically based hermeneutic, worldview, lifestyle practice and hope, and remains the only consistent approach to Islam. Though often overlooked in the search for a better "adapted" method, it remains the only method that ultimately produces the greatest good. 


\section{BIBLIOGRAPHY}

ANDERSON, J.

1998. Behold! The Ox of God! Evangelical Missions Quarterly 34 (3):1-3. [Online.] Retrieved from: http://bgc.gospelcom.net/emis/1998/oxofgod.htm.

Christie, V.

1999. Hudson Taylor. Founder of the China Inland Mission. Urichsville Ohio: Barbour.

DEEDAT, A.

1983. Christ in Islam. [Online.] Retrieved from: http://www.ahmed-deedat.co. za/books/Books/Christ\%20In\%20Islam/index.html.

DOUGLASS, R.C.

1994. Ongoing strategy debate in Muslim missions. International Journal of Frontier Missions 11(2):69-73.

EENINENBURG, D.

1997. The pros and cons of Islamic contextualization. Evangelical Missions Quarterly 33(3):310-315.

FRITZ, P.J.

1995. Contextualizing the message through case studies. International Journal of Frontier Missions 12(3):147-152.

HeIBERT, P.G.

s.a. The gospel and culture. In: D. McCurry (ed.), The Gospel and Islam: a compendium. The World of Islam [CD ROM]. Colorado Springs, Global Mapping International.

Hesselgrave, D.J.

1984. Contextualization and revelational epistemology. In: E.D. Radmacher \& R.D. Preus (eds.), Hermeneutics, inerrancy, and the Bible (Grand Rapids, Mi.: Zondervan), pp. 691-738.

1995a. Contextualization that is authentic and relevant. International Journal of Frontier Missions 12(3):115-119.

1995b. Great commission contextualization. International Journal of Frontier Missions 12(3):139-145.

Hesselgrave, D.J. \& Rommen, E.

1989. Contextualization: meanings, methods, and models. Grand Rapids, Mi.: Baker.

KÄRKKÄINEN, V.M.

2000. Culture, contextualisation, and conversion: missiological reflections from the Catholic-Pentecostal Dialogue (1990-1997). Journal of Asian Missions 2(2):261-275.

KING, M.L.

1986. A knock at Midnight. In: J.M. Washingtoen (ed.), A testament of hope, the essential writings and speeches of Martin Luther King, Jr. (San Francisco, CA: Harper), pp. 497-504. 
Kraft, C.

2004. Contextualization theory in Euro-American Missiology. Lausanne Committee for World Evangelization. [Online.] Retrieved from: http://www.gospelcom.net/ lcwe/wemag/9709kraf.html:1-2.

1980. Dynamic Equivalence Churches in Muslim society. In: D. McCurry (ed.), The Gospel and Islam: a compendium, The World of Islam [CD ROM]. Colorado Springs, Global Mapping International.

LEFFEL, J.

2004. Contextualisation: building bridges to the Muslim community. [Online.] Retrieved from:http://www.xenos.org/ministries/crossroads/OnlineJournal/issue1/contextu.htm: $1-14$.

MADANY, B.

1995. Re-thinking missions today. Protestant Reformed Theological Journal. November. [Online.] Retrieved from: http://www.prca.org/prtj/nov95a.html:1-8.

MASSEY, J.

2000. God's amazing diversity in drawing Muslims to Christ. International Journal of Frontier Missions 17(1):5-14.

Moreau, A.S.

2004. Section 1. Defining contextualization and related issues. In: Intro 532: Contextualisation (Wheaton, Illinois: Wheaton College), pp. 1-34.

1995. The human universals of culture: implications for contextualization. International Journal of Frontier Missions 12(3):121-125.

MUSK, B.A.

1995. Touching the soul of Islam. East Sussex: Crowborough.

PARshall, P.

2004. Lifting the Fatwa. Evangelical Missions Quarterly 40(3):288-293.

2001. My thirty year odyssey with contextualization. In: Adventist Frontier Missions consultation on Muslim evangelism (Melun: Parshall), pp. 1-4.

1998. Danger! New directions in contextualization. Evangelical Missions Quarterly 34(4):404-406, 409-410.

1980. New paths in Muslim evangelism. In: D. McCurry (ed.), The World of Islam [CD ROM]. Colorado Springs, Global Mapping International.

Plastow, F.

1999. Trends in Missions-Contextualization. Voice. [Online.] Retrieved from: http:// www.ifca.org/voice/99Jan-Feb/plastow.htm:1-3.

POLLOCK, J.

1955. The Cambridge Seven. London: Inter-Varsity.

SCHANTZ, B.

1993. Your Muslim neighbor and you. Stanborough England: Stanborough Press. 


\section{SHLORFF, S.P.}

1980. The theological and apologetical dimensions of Muslim Evangelization. Westminster Theological Journal 42(2):335-366.

SMITH, R.A.

2004. The trinity and contextualisation. In: Essays [Online.] Retrieved from: http://www.berith.org/essays/trin_contxt:1-10.

TRAVIS, J.

2000. Messianic Muslim followers of Isa. A closer look at C5 believers and congregations. International Journal of Frontier Missions 17(1):53-59.

WELLMAN, S.

1995. David Livingston Missionary and explorer. Urichsville, Ohio: Barbour. 1997. William Carey. Father of modern missions. Urichsville, Ohio: Barbour.

WHELCHEL, J.R.

2000. Ethnohermeneutics: a response. Journal of Asian Missions 2(1):125-133.

WILLIAMS, M.S.

2003. Aspects of high spectrum contextualisation in ministries to Muslims. Journal of Asian Missions 5(1):75-91.

WILSON, J.C. JR.

1994. Undergirding the effort with prayer. International Journal of Frontier Missions 11(2):61-66.

Keywords

Missiologie

Muslims

Contextualisation
Trefwoorde

Sending

Moslems

Kontekstualisering 